Author's Post-print Version (i.e. final draft post-referring) for:

Jordan, J. C. (2014) Swimming alone? The role of social capital in enhancing local resilience to climate stress: a case study from Bangladesh. Climate and Development, DOI: 10.1080/17565529.2014.934771.

The published version can be found here: http://dx.doi.org/10.1080/17565529.2014.934771

\title{
Swimming alone? The role of social capital in enhancing local resilience to climate stress: a case study from Bangladesh
}

Joanne Catherine Jordan*

School of Planning, Architecture and Civil Engineering, Queen's University Belfast, Belfast, BT9 5AG, UK

`Email: joanne.jordan@manchester.ac.uk

\section{Abstract}

There has been increasing examination of resilience as a concept applicable to climate adaptation. In this paper, resilience is used to explore the layers of responses to past and present climate stress. It examines the factors and circumstances that may hinder or enhance resilience, providing insights into past and present adaptation processes that may be relevant for adaptation to future climate change. Specifically, this paper tests the value of social capital in influencing resilience to climate stress. While there are many examples where social capital influences resilience to climate stress, this paper aims to determine the relative importance of different types of social capital for enhancing resilience, by exploring how relationships of exchange and reciprocity influence responses to climate stress. This study involved case studies of specific communities in the southwest coastal region of Bangladesh. This case study highlights a complex rather than a uniformly positive relationship between social capital and enhancing resilience to climate stress. Specifically, it identifies four types of social capital-based support (with monetary support as a subset) and the interlinkages among the types (and processes) of social capital with diverse effects on resilience. It emphasizes the moral and ethical importance of reconceptualizing resilience with an emphasis on the most vulnerable, as resilience approaches that fail to recognize the differentiated nature of resilience, risk reinforcing vulnerability. Westernized concepts have 
important benefits, but crucial limitations when applied to the particular conditions, value sets and modes of community working in the south. The uncritical importation of social capital needs to be treated with caution, especially in the context of climate adaptation.

Keywords: resilience; social capital; vulnerability; climate stress; Bangladesh

\section{Introduction}

The IPCC (2007) has projected increased temperatures, sea-level rise and an increase in extreme weather events, which they conclude with high confidence is due to anthropogenic activity, with potentially devastating impacts on food production, health, loss of biodiversity and freshwater availability. Given that it is highly likely that observable manifestations of climate change will intensify over the coming decades, adaptation to address the potential impacts of unavoidable climate change requires urgent attention (e.g. Adger, Arnell, \& Tompkins, 2005; United Nations Development Programme, 2007). There has been increasing examination of resilience as a concept applicable to climate adaptation. It is top of the policy agenda with a number of government and non-government agencies (e.g. DFID, 2009; United Nations Environment Programme, 2008) relating resilience to climate variability and change. It is suggested that a resilient community can better withstand disturbances, self-organize and learn and adapt to change when required (Tompkins \& Adger, 2004). Similarly, the poverty literature emphasizes resilience as a dimension of vulnerability, in terms of the 'ease and rapidity of a system's response from stress' (Moser, 1998, p. 3).

There is a growing literature on the factors that influence resilience, with social capital becoming increasingly recognized as having a key role in enhancing resilience. Undoubtedly, social capital has become one of the main themes in global development work; it has been actively adopted as an alternative to government or market-based approaches, with the World Bank hailing it as 'the missing link' in development (Grootaert, 1997). Likewise, there is a growing interest in the concept of social capital by the climate change community as a factor that enhances resilience (e.g. Adger et al., 2007; Wolf, Adger, Loronzoni, Abrahamson, \& Raine, 2010). Pelling and High (2005, p. 317) argue that social capital offers ways into understanding the role of fundamental social attributes that contribute towards building capacity for social collectives and individuals to respond to climate change'. Social ties of everyday social interaction can be a valuable resource in building and maintaining resilience, through mechanisms, such as risk sharing, mutual assistance and collective action (Adger, 2003; Paton, Millar, \& Johnston, 2001). Indeed, Tompkins and Adger (2004) argue that social capital is an important element for coping (cf. 
reactive resilience) with climate stress and is central to adaptive capacity (cf. proactive resilience) (Adger et al., 2007), which is particularly important for critical transformations in the context of climate change.

However, while there are many examples where social capital influences resilience to climate stress, there is limited in-depth research on the specific role of social capital in enhancing resilience, in particular research that highlights a complex rather than a uniformly positive relationship between social capital and enhancing resilience. Indeed, the climate change community could reflect on the experiences and failures of social capital in research and policy in parallel policy areas, such as development (see Fine, 2010; Law \& Mooney, 2006). Harriss (2002) contends that social capital represents problems that are rooted in differences of power and in class relations as technical issues that can be addressed outside political spaces, thus 'depoliticizing development'. Therefore, a critical appraisal of social capital is essential to ensure that the concept is not transferred uncritically into research and policy discourses on climate adaptation.

This paper aims to determine the relationship between social capital and resilience to climate stress, by examining how different types of social capital affect the nature of resilience. This will help draw attention to the way social and power differentials affect resilience with diverse repercussions on vulnerability. Thus, this paper begins by exploring the conceptual linkages between resilience and social capital; in particular, it presents a continuum of resilience, specifying the different types of social capital that are linked to its various stages. It then outlines the empirical approach adopted for this study and examines the relative importance of different types of social capital-based support for enhancing resilience, by exploring how relationships of exchange and reciprocity influence responses to climate stress. This highlights that reciprocation - non-monetized and monetized trading leads to an emphasis on economic capital albeit in localized ways. Finally, it concludes by appraising social capital and the limits to resilience, highlighting the moral and ethical importance of reconceptualizing resilience with an emphasis on the most vulnerable.

\section{Framing the issue: resilience and social capital}

Resilience is a complex concept with contested definitions and relevance (see Brand \& Jax, 2007). There are as with social capital multiple interpretations that direct very different community practices and political outcomes. Indeed, the way resilience is currently used does not suggest radical change; it is aimed at maintaining the broader status quo (i.e. maintain business as usual development paths), rather than engaging in political debate 
concerning the underlying factors that determine vulnerability to climate variability and change. This interpretation of resilience is appealing to governments, multilateral and bilateral agencies, as something that can be achieved through persistence and robustness of the current system. Resilience has been used to push social risks, such as flooding, to the community level under the guise of new localism, in the Strategic national framework on community resilience (Cabinet Office, 2011). Such references to localism and decentralization are being used to directly question state intervention, regulation and the public sector (Featherstone, Ince, Mackinnon, Strauss, \& Cumbers, 2012). Similarly, the World Bank's (2009) Strategy for sub-Saharan Africa seems to interpret resilience to climate change as something that can be achieved by fixing the current system through climateproofing development. Such interpretations of resilience, with a focus on maintaining business as usual development paths, risk reinforcing vulnerability.

Similar to Pelling (2003) and Moser (1998), it is argued here that resilience is a key determinant of vulnerability. While it may seem obvious that a resilient system is less vulnerable than a non-resilient one, it is argued that such reasoning is overly simplistic and under-emphasizes the complexity of the relationship between resilience and vulnerability. Therefore, this paper differentiates between reactive (cf. coping) and proactive resilience (c.f. adapting) (Dovers \& Handmer, 1992). Reactive resilience focuses on strengthening the status quo and creating resistance to change, thus it can strengthen the current political and government regime or trajectory of change, as it involves actions and activities that occur within existing structures. In contrast, proactive resilience emphasizes the inevitability of change and aims to establish a system that is able to adapt to new circumstances (see Walker et al., 2002). This is an important broadening of the traditional interpretation of resilience, which focuses on persistence and robustness of the system (i.e. ability to stay the same), based on the premise of resilience being tested by an initial perturbation. This highlights that resilience allows for the advancement of the state through flexibility to experiment, learn and adopt innovative solutions and transform (Walker et al., 2002). This is sometimes referred to as adaptive capacity, which Smit and Pilifosova (2001, p. 881) define as 'The potential or ability of a person, group or system to adapt'.

Therefore, it is argued here that adaptive capacity implies the potential ability to enhance proactive resilience, which often involves structural changes to address the underlying causes (rather than symptoms) of vulnerability to climate variability and change (see Klein, Nicholls, \& Thomalla, 2003). In contrast, coping capacity suggests the potential ability to enhance reactive resilience, which frequently involves strengthening the status quo and making the present system resistant to change. Therefore, a tension exists between 
maintaining the resilience of a current configuration (fixing the current system) and building a capacity for transformability (seeking a new, potentially more desirable state) (Gallopín, 2006; see O'Brien, 2011; Park et al., 2012). In other words, a balance between absolute rigidity and total flexibility (Gupta et al., 2010), as too much of either can lead to collapse (Folke, 2006). However, in many contexts resilience may require improving or transforming rather than maintaining undesired trajectories (Boyd et al., 2008).

This continuum of resilience from reactive to proactive can be further enriched by including social capital. Social capital is a multifaceted concept with contested definitions and interpretations. There are few writers who have raised the status of social capital more than Robert Putman. Putnam (1995, p. 665) defines it as 'features of social life - networks, norms, and trust - that enable participants to act together more effectively to pursue shared objectives [...]. Social capital, in short, refers to social connections and the attendant norms and trust'. As such, three aspects of social capital are usually identified: networks, norms and trust. Indeed, social capital's emphasis on promoting greater community self-reliance and empowerment by reducing the powers of the state and encouraging volunteering and community activity often 'seems to be a way of expecting groups of people who are poorly resourced to pull themselves up by their collective boot straps' (Levitas, 2000, p. 196). Thus, the western notion of social capital and reactive resilience can be reduced to the same minimalist points.

While it is acknowledged that social capital can be classified in a number of ways, for the purpose of this discussion, the analysis will focus on the common categorization of social capital, as bonding, bridging and linking social capital networks, as outlined by Woolcock (2001).

- Bonding social capital - characterized by 'strong ties'; dense network structures and strong, but localized trust. For example, relationships between family members; friends; and neighbours sharing similar demographic characteristics.

- Bridging social capital - characterized by 'weak ties'; less dense, but more crosscutting ties (between people from different ethnic; geographical; and occupational backgrounds, but with similar economic status and political influence). For example, links with others in the village or local area, such as village leaders.

- Linking social capital - characterized by weaker bonds of risk and reciprocity. For example, links with outsiders to the village who have more political or economic power, operating through formal hierarchical structures, such as government officials. 


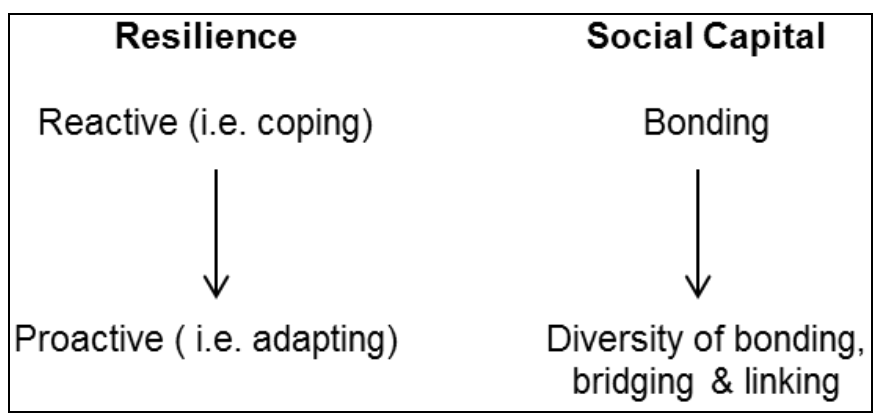

Figure 1 Continuum of resilience: links to social capital.

Social capital does not necessarily increase resilience (in particular proactive resilience). Figure 1 suggests that bonding social capital is most often used for reactive action (Osbahr, Twyman, Adger, \& Thomas, 2010), while a diversity of types of social capital is used in more forward-looking adaptation. Bonding social capital is associated more as an important component of coping with the impacts of climate stress (i.e. reactive resilience). Therefore, it is more likely to involve actions and activities that occur within existing structures (i.e. strengthening the status quo). It can increase solidarity and cohesion and can provide crucial networks for mutual support among groups that have a common array of interests. For example, Sutherland, Smit, Wulf, and Nakalevu (2005) note that village inhabitants of Samoa in the south Pacific rely on kinship networks at the local level to provide nonmonetary support, such as food, during times of stress, and remittance sent from relatives working overseas. However, bonding social capital does not appear to enhance proactive resilience as it can discourage experimentation and more radical or transformative forms of change. For example, it can reduce the flow of information due to a lack of interaction between networks with cross-cutting ties (see Wolf et al., 2010). Furthermore, a network composed of only bonding ties can impose strict social norms that make numerous demands on group members, and reduces group diversity and individual autonomy (Portes, 1998). This can act as a barrier to enhancing resilience as it may limit 'acceptable' strategies to cope with, and adapt to, stress (Newman \& Dale, 2005).

In contrast, Figure 1 suggests that a diversity of types of social capital is critical for enhancing proactive resilience. In particular, it may provide access to a range of support beyond local networks, which is crucial for responding to climate stress (Newman \& Dale, 2005). Bridging ties can allow people to overcome social norms with support beyond their local network (Newman \& Dale, 2005). It can provide access to resources, new information and opportunities in other networks (Granovetter, 1973), whereas linking social capital involves vertical ties with those that have more political or economic power, for example 
receiving assistance or advice from government agricultural extension on cultivating saline tolerant rice. Furthermore, Adger (2003) notes the importance of the interaction of individuals and groups with the state in responding to climate change. In other words, a diversity of bonding, bridging and linking social ties seems to be more important for experimentation, learning and innovations that address the underlying causes of vulnerability to climate variability and change.

Therefore, when examining the linkages between social capital and resilience, it is important to consider how different types of social capital affect the nature of resilience. Are bonded networks enough to proactively facilitate innovation to climate stress (see Osbahr et al., 2010)? Is a diversity of bonding, bridging and linking social capital crucial to building more proactive forms of resilience? While this paper acknowledges social capital's multifaceted nature, it will examine the relative importance of different types of social capital for enhancing resilience, through primarily exploring how relationships of exchange and reciprocity influence responses to climate stress. The analysis will involve examining monetary and non-monetary support provided by a range of social networks, from familial and kinship networks to broader institutional support networks. Specifically, this approach will draw attention to the positive and negative aspects of social networks, leading to increased understanding of the social and power-related connotations of resilience, which is imperative for building resilience to climate variability and change for the most vulnerable.

\section{Case study: southwest Bangladesh}

This paper is based empirically on a case-study research in Bangladesh, which has been identified as one of the most vulnerable countries to both current variations in climate and future climate change (see Agrawala, Ota, Ahmed, Smith, \& van Aalst, 2003; Huq \& Ayers, 2008). The aim of this empirical research was to provide insights into past and present adaptation processes that may be relevant for adaptation to future climate change (see Adger, Huq, Brown, Conway, \& Hulme, 2003). Specifically, it tests the value of social capital in influencing resilience to climate stress. The case-study villages selected for this research were Kolatola (case-study village 1) in Chila Union and South Kainmari (case-study village 2) in Chandpai Union, both of which are located in Mongla Upazila, under Bagerhat district in southwest Bangladesh (Figure 2). Kolatola and South Kainmari were chosen as a suitable case study for this research because of their vulnerability to a range of climate stresses, perceived high proportion of poor village inhabitants, ' the support of a regional and local nongovernmental organization (NGO), the availability of entry points into the villages and logistical issues (e.g. accessibility). 


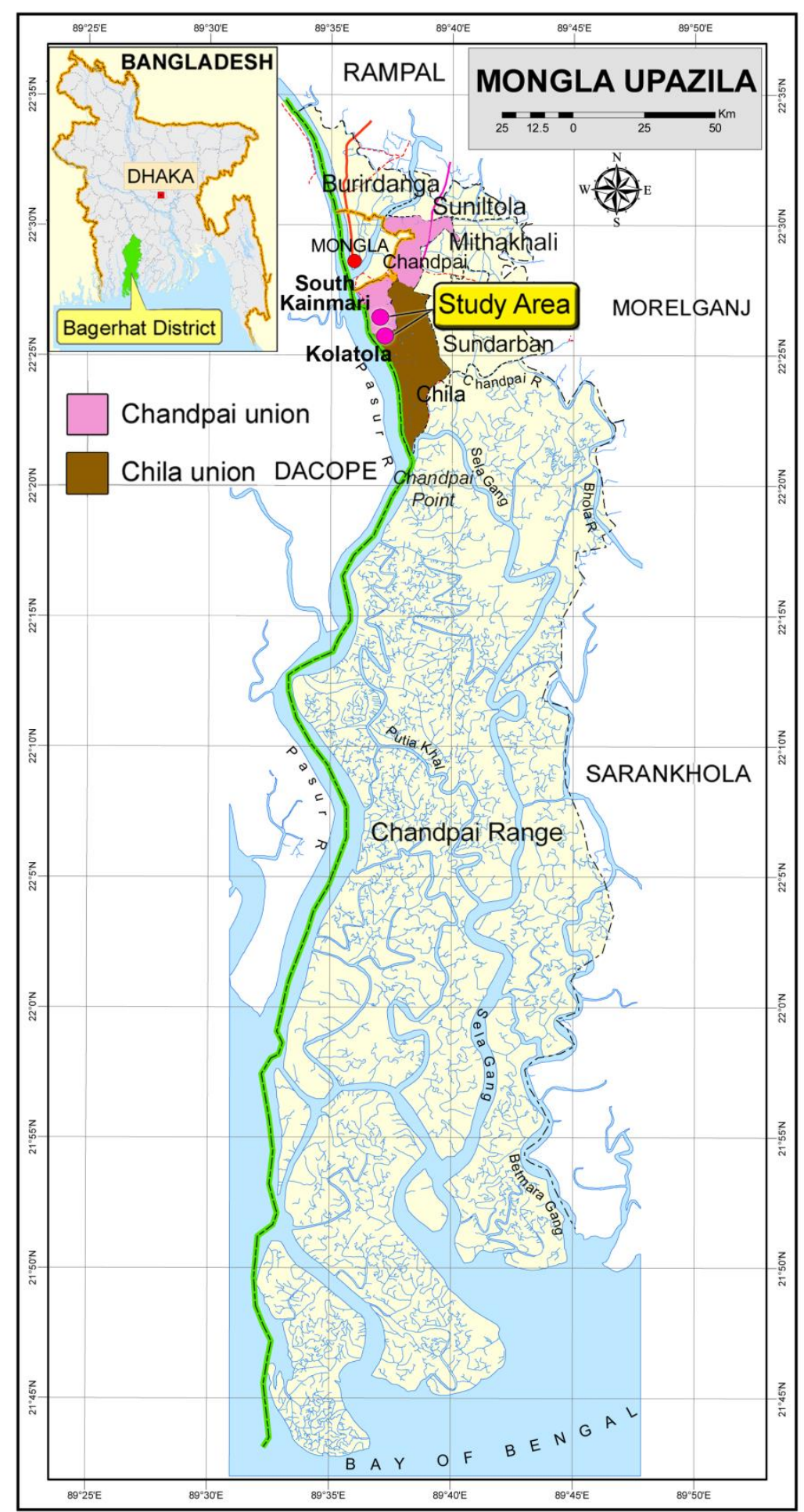

Figure 2 Case study location.

Source: Adapted from Asiatic Society of Bangladesh (2008).

The case-study villages' location in the risk prone coastal region makes them vulnerable to cyclone and storm surges; sea-level rise; salinity intrusion and riverbank erosion. Cyclones and salinity intrusion were identified by village inhabitants as the most critical climate-related 
stresses they experience. The case-study villages have suffered from huge cyclone damages. In 2007, Cyclone Sidr is estimated to have affected 8.5 million people in Bangladesh; it killed 3406 people, damaged nearly 1.5 million houses, destroyed 2.4 million acres of crops and killed 1.2 million livestock (Alam, Hussain, Hossain, \& Saadi, 2009; Government of Bangladesh, 2008). Overall, economic losses incurred from Cyclone Sidr have been calculated at US\$1.7 billion (Government of Bangladesh, 2008). Bagerhat district, where both case-study villages are located, was one of the worst affected districts, with $62.22 \%$ of the population affected. Salinity is also a major problem for those living in the case-study villages. In 2005 approximately $55 \%$ of the population were affected by medium ( $<5$ parts per thousand) or high salinity ( $>5$ parts per thousand) in Bagerhat, with $23 \%$ of the population affected by high salinity. This has led to a range of impacts on livelihoods, including loss/sickness of livestock and poultry; loss of crops and loss of local fish species. In addition, this reduction in fresh water supply has led to a range of health effects, including diarrhoeal diseases; skin diseases; pre-eclampsia; eclampsia and hypertension (see Khan, Mojumder, Kovats, \& Vineis, 2008).

The key characteristics of the case-study villages are shown in Table 1. Mallick and Alauddin's (2010) baseline survey highlights that $47.7 \%$ of households are engaged in fisheries and $4 \%$ of households are engaged in agriculture, while over $25 \%$ of households are agriculture-based labourers. The average income of households per year is 35,492 tk. (approximately $£ 354.92$ ) ${ }^{\mathrm{ii}}$ and $69 \%$ of households experience food insecurity for three to four months per year (Mallick \& Alauddin, 2010).

Table 1 Key characteristics of case-study villages.

\begin{tabular}{|c|c|c|}
\hline & Case study Village 1 & Case study Village 2 \\
\hline Village & $\begin{array}{l}\text { Kolatola (Chila union, Mongla } \\
\text { Upazila, Bagerhat District) }\end{array}$ & $\begin{array}{lrr}\begin{array}{l}\text { South } \\
\text { union, }\end{array} & \text { Kainmari } & \text { (Chandpai } \\
\text { Bagerhat District) } & \text { Upazila, }\end{array}$ \\
\hline Population & 350 & 1,285 \\
\hline Religion (majority) & Hindu & Christian \\
\hline Major livelihoods & $\begin{array}{l}\text { Fisheries (fishing, shrimp } \\
\text { culture, fish fry collection, fish } \\
\text { based business), agricultural or } \\
\text { non-agricultural wage labour } \\
\text { and small businesses }\end{array}$ & $\begin{array}{l}\text { Fisheries (fishing, shrimp } \\
\text { culture, fish fry collection, fish } \\
\text { based business), agricultural or } \\
\text { non-agricultural wage labour } \\
\text { and small businesses }\end{array}$ \\
\hline Land use pattern & $\begin{array}{l}\text { Cropland, shrimp cultivation, } \\
\text { homestead }\end{array}$ & $\begin{array}{l}\text { Cropland, shrimp cultivation, } \\
\text { homestead }\end{array}$ \\
\hline Crops & $\begin{array}{l}\text { Paddy, vegetables, coconut, } \\
\text { betel nut }\end{array}$ & $\begin{array}{l}\text { Paddy, vegetables, coconut, } \\
\text { betel nut }\end{array}$ \\
\hline Fruit/vegetables & papaya, & papaya, \\
\hline
\end{tabular}




\begin{tabular}{|l|l|l|}
\hline $\begin{array}{l}\text { cultivated in } \\
\text { homestead }\end{array}$ & $\begin{array}{l}\text { tomatoes, potato, chilli, } \\
\text { spinach, lentils, eggplant, } \\
\text { cabbage and cauliflower }\end{array}$ & $\begin{array}{l}\text { tomatoes, potato, chilli, } \\
\text { spinach, lentils, eggplant, } \\
\text { cabbage and cauliflower }\end{array}$ \\
\hline Sources of water & River, pond, rainwater & River, pond, rainwater \\
\hline $\begin{array}{l}\text { Climate stress } \\
\text { (worst in italics) }\end{array}$ & $\begin{array}{l}\text { Salinity, cyclones, river bank } \\
\text { erosion and floods }\end{array}$ & $\begin{array}{l}\text { Salinity, cyclones, river bank } \\
\text { erosion and floods }\end{array}$ \\
$\begin{array}{l}\text { Key problems or } \\
\text { needs (climate or or } \\
\text { non-climate } \\
\text { related) }\end{array}$ & $\begin{array}{l}\text { Lack of available work, income } \\
\text { insecurity, fishing restrictions, } \\
\text { lack of drinking water, lack of } \\
\text { agricultural land due to } \\
\text { riverbank erosion and salinity. }\end{array}$ & $\begin{array}{l}\text { Lack of available work, income } \\
\text { insecurity, fishing restrictions, } \\
\text { lack of drinking water, lack of } \\
\text { agricultural land due to } \\
\text { riverbank erosion and salinity }\end{array}$ \\
\hline
\end{tabular}

This study is based on a case-study research, primarily following a qualitative and interpretative approach. The qualitative data from the main data-gathering phase of this study are based mostly on in-depth one-to-one semi-structured interviews with 38 village inhabitants, including key informants (e.g. informal village leaders and informal moneylenders) and 12 focus group discussions with 65 village inhabitants from the casestudy villages. Participants were selected through random stratified sampling, with gender identified as a subgroup. While gender was the only identified subgroup, the selection of participants was frequently examined to ensure that a broad range of subgroups were included in the sampling frame.

The semi-structured interviews and focus group discussions incorporated features of both standardized open-ended interview and interview guide approach. While the wording and sequence of questions and associated probes ${ }^{\mathrm{iii}}$ were determined in advance, the style of interviewing was flexible and adaptive, so the questions asked and the depth of responses to these questions varied between interviewees. However, each interview and focus group followed a similar overarching format, which involved discussion on the following key categories of questions: (1) Community priorities and needs, (2) Community perception and understanding of climate-related stresses, (3) Ranking of climate-related stresses, (4) Impacts of climate stresses, (5) Responses to climate stresses and how these were influenced by social capital and (6) Community decision-making and dynamics. ${ }^{\text {iv }}$ These topics were derived from a comprehensive literature review, discussions with experts working on climate adaptation, social capital and/or development and a scoping study of Bangladesh, which included exploratory visits to several communities in different regions of Bangladesh. 


\section{Relationships of exchange and reciprocity}

This section will examine the relative importance of different types of social capital for enhancing resilience, primarily through exploring how relationships of exchange and reciprocity influence responses to climate stress. The case study identifies four types of social capital-based support, for which monetary support is a subset (see Table 2). v

Table 2 Types of social capital based support for enhancing resilience.

\begin{tabular}{|l|l|}
\hline Type of Support & Examples \\
\hline Informal monetary: bonding social capital & $\begin{array}{l}\text { Credit and lending arrangements between } \\
\text { family, friends, neighbours and moneylenders }\end{array}$ \\
\hline $\begin{array}{l}\text { Formal monetary: bonding and bridging } \\
\text { social capital }\end{array}$ & NGO based microcredit \\
\hline $\begin{array}{l}\text { Informal nonmonetary: bonding social } \\
\text { capital }\end{array}$ & $\begin{array}{l}\text { Food lending arrangements between family, } \\
\text { friends and neighbours }\end{array}$ \\
\hline $\begin{array}{l}\text { Formal nonmonetary: bonding bridging } \\
\text { and linking social capital }\end{array}$ & $\begin{array}{l}\text { NGO and government allocation and } \\
\text { distribution of relief }\end{array}$ \\
\hline
\end{tabular}

\subsection{Monetary support}

\subsubsection{Informal monetary support}

This section will focus on strategies based on reciprocity and exchanges, in particular informal credit and lending arrangements between family, friends, neighbours, colleagues and traders, which rely mostly on bonding social capital. This is important for understanding resilience, in particular reactive resilience, as bonding social capital can provide crucial networks for mutual support during times of stress. While the case study suggests that access to familial and kinship networks can enable people to cope with stresses, there appears to be limited potential for such networks to allow people to adapt to stresses, as the level of monetary support these networks can provide is limited, given the level of poverty. However, a minority of village inhabitants have access to familial networks that provide monetary gifts or lend money with no interest or obligation to reciprocate exchange, which can act as a buffer against the effects of shocks. In case-study village 2, there is greater access (albeit still limited) to such forms of familial support, as there are more families that have the economic capacity to extend more flexible forms of monetary support compared to case-study village 1 . Also other households can borrow money from close neighbours with no interest or a low interest rate (5-10\% interest per month), compared to rates charged by 
conventional informal moneylenders (10-20 plus \% interest per month). This highlights that social capital clearly feeds from, and reproduces, economic capital.

While bonding social capital can provide important sources of coping, it cannot always be interpreted as positive. The majority of village inhabitants do not have access to familial or kinship networks that can provide significant monetary support with no or low interest and with no obligation to reciprocate exchanges in the future. Indeed, the case study highlights that the poorest households are unable to access familial networks that provide monetary support with flexible lending arrangements. However, some village inhabitants have access to relationships of reciprocity and exchange that allow them to borrow small amounts of money from close neighbours with no interest: for example, when money is borrowed for extremely short periods (i.e. one week) or when low interest rates are charged on loans of only two to three weeks. While this form of exchange and reciprocity provides important sources of coping for the poor (albeit restricted to reactive resilience), it has limited potential to create proactive resilience, as such short-term forms of lending are unlikely to provide sustained gains in the long term. Furthermore, access to even these short-term coping strategies is limited for the poorest as one interviewee explained:

'I do not borrow money from anyone [...]. Some people lend small amounts of money with no interest if you can pay it back in a short time. But, I would not be able to pay it back in a short period'. (Female household interview, \#16)

Furthermore, evidence suggests that access to familial or kinship networks that provide monetary support (i.e. bonding social capital) is dependent on strong bonds of trust based on the ability to repay loan and to reciprocate exchanges when necessary. 'Trust' in this context is based on access to economic capital. For example, a household with a high poverty level may not be able to assure a lender that the loan will be repaid. In this case, trust is clearly specific and contextual. Money creates confidence that the loan will be repaid. As a village inhabitant explained:

'When we go to borrow money from neighbours, they want us to show them something to guarantee that we will pay them back. We have nothing to mortgage so they do not give us money [...]. Our close relatives do not give us money [...]. We are very poor so they cannot trust us to pay them back'. (Female household interview, \#21)

This is one of the examples discovered in the case study that highlights the fragility of informal networks for providing mutual support during times of stress. It seems that the 
evidence of internal exchange systems based on money lending providing increased or even secure benefits to the poor is limited; that is, creating an enabling environment for the whole spectrum of the poor to cope with, and adapt to, stress. In other words, there appears to be little potential for this strategy to create sustained gains for the poorest of the poor (i.e. destitute), ${ }^{\text {vi }}$ as the case study suggests that they are excluded from familial, kinship or community-based support systems due to limited or no assets (e.g. lack of economic capital to repay loans). Furthermore, this case study highlights that the ability of internal exchange systems providing mutual support during times of stress appears to be particularly limited for covariate shocks as everyone is affected. This is similar to Traerup's (2012) study in Tanzania, which found that informal networks are insufficient to deal with covariate shocks since the majority of risk-sharers will be affected by the shock at the same time. Furthermore, this can vary according to the type of covariate risk. For example, internal exchange systems seem to be particularly ineffective in the case of cyclones compared to salinity intrusion, which is a slow onset disaster. Cyclones are sudden onset disasters that can destroy or disrupt the livelihoods of a large number of people; as a household's economic capital declines it can become more challenging to commit time and resources to familial or kinship networks, as one interviewee explains:

'During cyclone everyone is busy with their own dwelling and lives. So, I only look after my family and myself. When it is cyclone we cannot help others [...]. During high salinity we can go all together to bring water from far distance'. (Male household interview, \#9)

Therefore, given the inadequacy or low level of support provided by the majority of familial and kinship networks, the poor are often 'forced' into borrowing from informal moneylenders, indicating that they have fewer and often inflexible strategies available. While this case study highlights the importance of networks based on informal money lending, in particular to provide short-term coping mechanisms, the findings indicate that even access to this form of informal credit is dependent on a household's asset base (e.g. land), as collateral is required to secure loans. These exchange systems clearly exclude the poorest of the poor who already have limited choices and strategies to cope with, and adapt to, climate stress. While for those that are able to access informal credit, the relationship between those who lend and borrow is sometimes based on exploitation. This can be interpreted as a negative form of reciprocity based on the ability to pay exploitive interest rates of $10-20 \%$ plus per month. Furthermore, incentives to adhere to obligations (i.e. repay loan) can include harassment and intimidation, and in a minority of cases physical assault. This clearly highlights the importance of not only focusing on the potential economic support provided by networks, but also recognizing the effects of accessing such forms of support, particularly on psychological 
and emotional aspects of well-being, particularly on the most vulnerable. Therefore, this paper questions the ability of networks of informal money lending to provide support during times of stress.

The case study emphasizes that some groups, such as informal moneylenders, capitalize on information available in networks (in this case based on bonding social capital) to accrue greater individual benefits, though this is achieved through exploitative practices, which may create negative outcomes for poor people. This highlights the dark side of social capital; information is available in networks, which allows informal moneylenders to develop an increased understanding of a borrower's circumstances, allowing them to charge higher interest rates when a person is experiencing a crisis, as 'they know you are desperate for money':

'Village moneylenders usually charge more interest when you are in a crisis [...]. They charge interest rate from 150-200 tk. per month [15-20\% interest per month]. If you are in a big crisis, they charge more [...]. After Sidr, these people charged higher interest rates'. (Male household interview, \#42)

The disadvantages of seeking loans from those whom you may have close social ties with is further illustrated by the fact that village inhabitants appear to be able to borrow at a lower interest rate if the lender is from outside the village. This seems to be due to moneylenders living outside the village of a borrower having less information on a borrower's circumstances compared to a moneylender living in the same village as the borrower. However, not all village inhabitants are able to access this form of informal money lending due to a range of factors, for example, transport costs to informal moneylenders who live outside of the case-study villages. This is particularly the case for village inhabitants living in case-study village 1 compared to case-study village 2 , as they have lower levels of economic capital available (i.e. lack of economic capital to pay for transport) to access this form of monetary support.

\subsubsection{Formal monetary support}

The previous section's examination of informal networks of social capital highlights various aspects of dysfunctional internal exchange systems. Therefore, this section will explore the potential to strengthen internal exchange systems by developing formal investment models via NGOs, specifically microcredit (e.g. Grameen Bank). Microcredit was developed in response to the poor often lacking access to traditional forms of credit due to a lack of 
collateral, employment instability and a lack of verifiable credit histories. Microcredit attempts to overcome these problems by extending small loans, which are aimed at reducing poverty through fostering self-employment in low-income communities (Yunus, 1999). ${ }^{\text {vii }}$

Collective action groups, such as NGO-based microcredit groups, can usually be characterized as having bonding and bridging social capital. The case study shows that microcredit interest rates (vary according to the type of loan; majority of loans at $10-12.5 \%$ total interest) are substantially lower than those of the traditional moneylender, which as confirmed in this study may range from $10 \%$ to $20 \%$ plus per month. Thus, access to NGObased microcredit can allow the poor to avoid exploitative relationships with moneylenders. While microcredit groups are not formed with the specific objective of providing strategies to respond to climate stress, nevertheless, the case study suggests that it can contribute to resilience. For example, microcredit can potentially create opportunities to diversify into economic activities that are not dependent on climate sensitive economic activities (i.e. proactive resilience). This can reduce the direct impact of climate stress on a household's livelihood, and/or enable borrowers to cope with climate impacts through an increased ability to recoup their losses (i.e. reactive resilience).

However, while microcredit members may be less vulnerable during times of stress compared to non-members, this study highlights that for the majority of village inhabitants, microcredit creates limited capacity to develop proactive resilience. There are cases of borrowers taking overlapping loans, using one loan to pay another loan or using microcredit for non-productive purposes, such as buying their children's clothes. While using microcredit for these purposes is essential in these cases (and can increase reactive resilience), this clearly leads to problems in repaying loans, and questions the applicability of microcredit as a means for the poorest to move beyond coping mechanisms towards strategies that create proactive resilience to stresses, such as climate stress. Moreover, this case study indicates that vulnerability to climate stress can limit sustained gains in enhancing resilience. The evidence highlights that when the assets borrowers invest in (with the finance secured through microcredit) are destroyed, they have to continue to repay this loan. This can increase risks of loan default and even increased debts.

'We own shop [...] and poultry, we got all these things from taking loans [...]. During Sidr I lost my house and poultry house [...]. Sidr affected our income; we had less [...]. We used to have a trawler, but after Sidr I did not have enough money. So we sold it and used it to pay back loan [...]. [We had to] borrow 13, 000 tk. To rebuild the shop'. (Female household interview, \#33) 
In this case, social capital is rendered meaningless in responding to stress, as some village inhabitants had no other available option but to sell assets in order to meet repayments of loans taken before a specific climate event. While a small number of microcredit institutions had the financial capacity to suspend loan repayments, that is to introduce a contingent repayment system for their members who were affected by Cyclone Sidr in the case study villages, there was no access to immediate post-disaster microcredit (i.e. majority of interviewees had no access to microcredit until three plus months after Cyclone Sidr). This is particularly devastating as the abrupt nature of some climate events, such as cyclones, means that economic capital is required within a short time period; when overall cash flows have declined, not only is there a lack of microcredit available, but access to familial and kinship networks providing monetary support is also limited. In such situations, poor people may be 'forced' into borrowing from informal moneylenders with exploitative interest rates, given that they have fewer and inflexible strategies available (e.g. reduced ability to secure loans from familial and kinship networks affected by covariate shocks). This highlights the importance for new types of credit mechanisms that can be grounded in longer-term concepts of resilience and those that come into force at times of acute need when economic capital is required within a short time period.

The previous sections highlight that for those who can access microcredit there are a range of barriers that can limit its potential to enhance resilience. Furthermore, the evidence highlights that not all households have access to microcredit; this was found to be the case particularly in case-study village 1 , as there are a greater number of households that lack the economic capital to pay membership fees and monthly instalments compared to case-study village 2. This case study concurs with Roodman and Morduch (2009) to suggest that many microcredit groups exclude the poorest. For example, membership fees create a barrier for poor people to participate in microcredit groups. As one village inhabitant explains:

'Richer families can deal with salinity better because they are members of different NGOs and are part of their loan service. They can take loans because they can [pay membership] fee [and monthly instalments] for loan. [...] We cannot afford to pay monthly fees'. (Female household interview, \#7)

In other words, social capital for one group of people (benefits accrue to microcredit group members) may mean 'social exclusion' for others who cannot afford to participate in such networks, or when they are included, inability to continue to pay loan instalments is a barrier for retaining membership. Furthermore, there are differential benefits for those participating 
in social networks, as some individuals will be able to accrue greater individual benefits compared to others.

\subsection{Non-monetary support}

\subsubsection{Informal non-monetary support}

There are other informal systems of exchange that occur mostly at the individual and household level that are more flexible than money lending arrangements (e.g. borrowing food), which act as vital coping mechanisms during times of stress. The case study found that village inhabitants in case-study village 1 were more reliant on informal systems of food exchange compared to inhabitants in case-study village 2 , as previous sections have highlighted that they have lower levels of access to informal and formal monetary support. However, these coping strategies based on exchange and reciprocity are limited or insufficient for many. The support these bonding ties provide can be low given the realities of unemployment or threatened livelihoods, which means that 'rational' decisions on whether to extend support to family members are made in the context of limited capital assets:

'My family do not share food with me; they only have enough food for themselves. The children are given priority, then my son-in-law, my daughter and then I only get food if it is left over [...]. Most of the times do not eat for two or three days a week'. (Female household interview, \#16)

In the context of intra-household dynamics, the case study highlights that when resources are limited, they are prioritized to particular members of a household. A range of factors influence this 'choice'; primarily food is prioritized to those household members who are perceived as having a greater ability to increase the household's capacity to respond to multiple stresses (i.e. usually male) while other household members are 'chosen to starve' (i.e. females, particularly elderly widows). This suggests that the potential for families to provide significant mutual support during times of stress, through trust and reciprocity, appears to be unrealistic in the context of the case study, given the socioeconomic and cultural fabric. This emphasizes the need to extend analysis to the uncritical treatment of relations within households, thus supporting Sen's (1990) cooperate conflict model.

During times of stress, such as a cyclone, there are instances of small-scale collective action. For instance, some households pool their food and share it; however, this is largely limited to familial and kinship networks. This allows people to cope until relief arrives, and 
allows them to prioritize provision of food to children during crises (enhances coping in the short term). Access to these collective activities is based on bonding social capital, and is dependent on the availability of food and close bonds of trust. Similar to Pelling (2003), the case study suggests that this form of collective action does not enhance proactive resilience; it is reactive resilience, which in this instance is in response to particular needs or opportunities (e.g. lack of food), rather than signifying more forward-looking adaptation. This form of social capital is episodic rather than durable and is rarely turned into an asset for local mobilization. It is important to highlight that these collective responses do not necessarily signify broader community cohesion, as they are based on support provided by familial and kinship networks (usually family, close neighbours and friends), rather than broader community-based collective responses.

Moreover, in some cases individuals do not engage in (reactive) collective action in order to bolster their own survival. As previous sections have suggested, acute stress can reduce mutual support; when a household's economic capital declines, it can become more challenging to engage in relationships of exchange and reciprocity. In other words, poverty and the lack of material resources defy the logic of collective-based actions, at the expense of economic or physical capital. This highlights the importance of addressing access to finance, capitalizing local communities and recycling local resources.

\subsubsection{Formal non-monetary support}

However, poor people's coping and adaptive strategies should not be limited to the support provided by familial, kinship or community-based networks, particularly those with other poor people, when they may be able to gain more from NGO and government assistance. Clearly, bridging and linking social capital are vital for access to NGO and government assistance. However, the ability to access and capitalize on institutional support is constrained by uneven power relations. In the case of allocation and distribution of relief, the case study emphasizes that some local informal and formal leaders after Cyclone Sidr reinforced their resilience, through inequitable allocation and distribution of relief (e.g. through reinforcing clientelism). For example, the union chairpersons ${ }^{\text {viii }}$ are involved in obtaining resources for their constituencies, through their political connections, such as lobbying for relief resources for their union. However, local leaders' accountability and legitimacy are to a certain extent affected by their ability to deliver favours to their acquaintances and to those who have elected them (i.e. patron-client relationships). In some cases, access to relief is dependent on economic capital, which is the ability to pay bribes to informal and formal leaders at the local level. 
'At first NGOs come here and make a list of [affected] people and then show it to Union Chairman and then if he permits the NGO can help those people. Chairman rejects names on the list because they cannot afford to bribe him [...]. I got a house from UNDP after Sidr, [as] I paid a bribe to the Chairman'. (Female household interview, \#22)

The case study evidence highlights that the practice of bribery continues due to fears that community divisions will occur if complaints are made against the practice of bribery; this prevents village inhabitants from challenging power differentials relating to allocation and distribution of relief. Furthermore, it was indicated by a village leader in one of the casestudy villages that the practice of bribery continues due to community fears that filing a case against the union chairperson or commissioner would affect their future allocation of relief. Indeed, this fear was alleged to have materialized in one of the case-study villages; it was claimed that a local NGO stopped working in the case-study village due to complaints regarding the practice of bribery:

'If someone needs house, but cannot give bribe, they will not get house. When NGOs come to work in community, they have to go to Union Chairman. If we complain that they are dishonest, then they will not work here. [An NGO] used to work here and when a complaint was made about bribery they left'. (Male group interview, \#30)

In contrast, Rotberg's (2013) study in Jamalpur, North Bangladesh, highlights the positive role that local village leaders play in community adaptation, through providing leadership and organizational management during flood times. However, this case study underlines that a lack of broader social cohesion can constitute a significant impediment during times of crisis. This finding corresponds with Mahmed and Prowse's (2012) study in southwest Bangladesh, which found that post-disaster interventions, such as food aid, suffered from greater levels, and worse types, of corruption than pre disaster interventions.

\subsection{Social capital-based support for enhancing resilience}

This paper has outlined four types of social capital-based support (with monetary support as a subset) that can enhance resilience to climate stress in the case-study area. Figure 3 maps these different types of support onto the resilience framework outlined in previous sections (see Figure 1). 


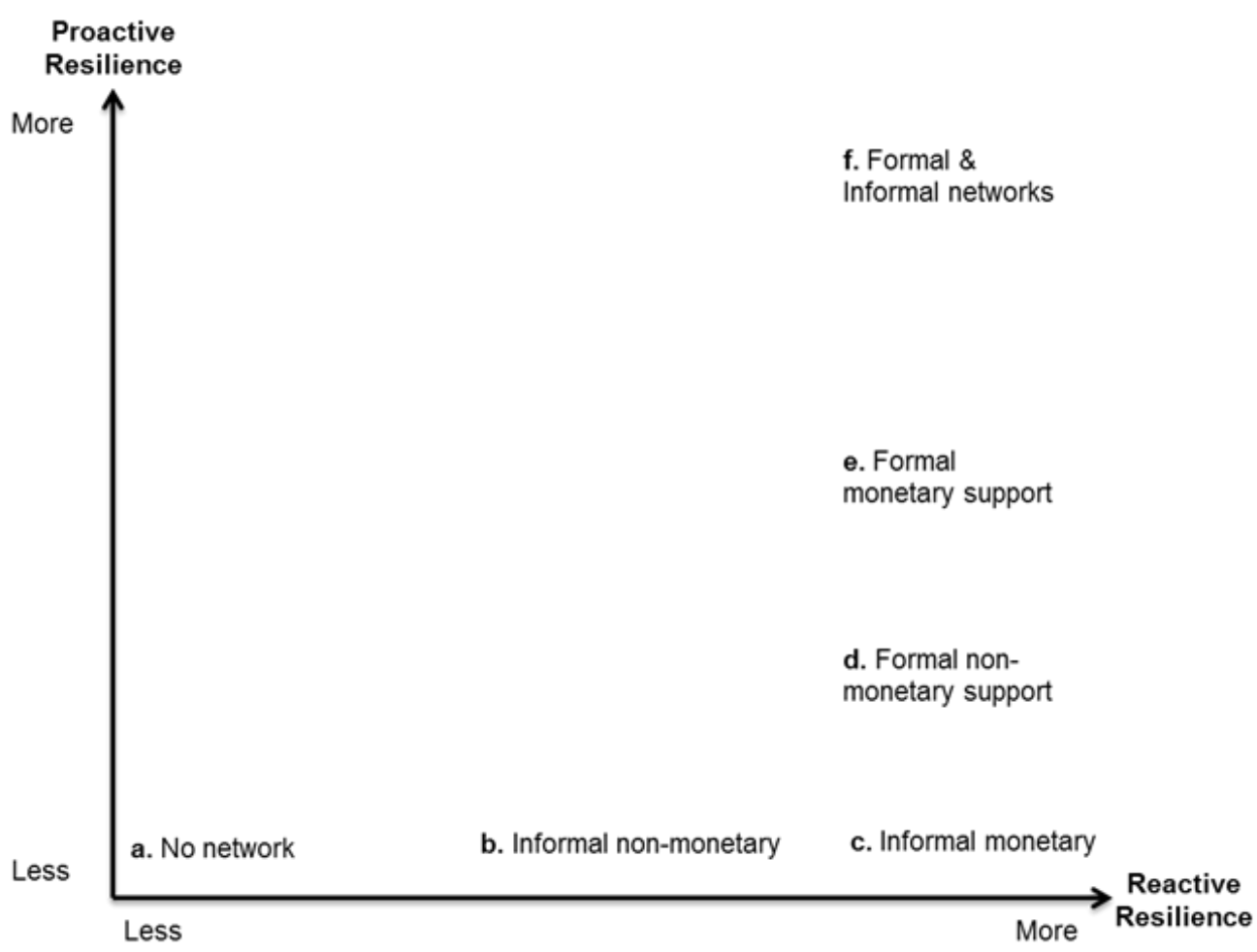

Figure 3 Social capital-based support for enhancing resilience.

While the case study evidence highlights that informal monetary support (i.e. bonding social capital) can provide important short-term strategies to cope with climate stress, it has limited potential to create proactive resilience, as these networks often provide low levels of monetary support and/or inflexible lending arrangements (sometimes exploitative) unlikely to provide sustained gains in the long term. In contrast, formal monetary support in the form of NGO-based microcredit is enabled by strong circuits of bonding and bridging social capital; bonding is needed because it enhances the necessary trust on which financial exchange is based and bridging because it permits access to outside sources of capital. Formal monetary support seems to have greater potential to enhance proactive resilience. For example, previous sections have highlighted that microcredit can create opportunities to diversify into non-climate sensitive economic activities, which can reduce the direct impact of climate stress on a household's livelihood, and/or enable borrowers to cope with climate impacts through an increased ability to recoup their losses. However, the evidence establishes that microcredit is largely limited to providing short- or medium-term coping strategies due to three key factors identified in the case study: lack of outreach; loan default and increased debt and supply barriers and credit alternatives.

The case study also highlights the potential of informal non-monetary support (i.e. bonding social capital) for enhancing reactive resilience, particularly when there is a lack of access to 
networks providing significant monetary support. While the evidence highlights that such forms of support do not enhance proactive resilience, they can provide important sources of coping in the immediate and/or short term with more flexible lending arrangements compared to moneylending. In contrast, access to formal non-monetary support in the form of NGO and government relief is dependent on bonding, bridging and linking social capital. This type of support can provide important sources of coping with the impacts of climate stress in the short term (e.g. food relief), and has the potential to enhance more proactive forms of resilience, through support to rebuild homes, particularly if this involves assistance to build houses that are more resistant to cyclones. However, the evidence highlights that the ability to access and capitalize on this institutional support is constrained by uneven power relations at the local level.

Furthermore, it is important to emphasize that the four types of social capital-based support evident in the case-study areas should not be interpreted as being mutually exclusive. Rather, each type is connected and can represent a progressive circuit, whereby each element reinforces each other to create more integrated strategies of resilience (type $f$ identified in Figure 3), or can act as an impediment for enhancing resilience (particularly proactive resilience). For example, one interviewee (\#16) explained that her household is excluded from familial, kinship and community-based forms of support (type a). Her household does not have access to microcredit (type e) due to a lack of economic capital to pay membership fees and to repay the loan. Similarly her household does not have access to informal monetary support (type c) as they are unable to assure the lender that they can repay the loan and reciprocate exchanges when necessary in the future. While the interviewee highlighted that they had access to relief after Cyclone Sidr, this was limited due to a range of factors, including lack of connection to informal and formal leaders involved in allocating and distributing relief; lack of economic capital to pay bribes to access relief and a lack of connection to NGOs providing relief compared to those village inhabitants who were members of NGO microcredit groups. While they had access to informal food lending (type b), this was limited to inflexible lending arrangements where food could only be borrowed for very short time periods, which led to the household taking overlapping food loans, using one food loan to repay another food loan. Furthermore, access to this type of support was then further limited within the household, with food prioritized to particular members of the family (i.e. with elderly widows more likely to be 'starved'). This corresponds with Pouliotte, Smit, and Westerhoff's (2009) study in Subarnabad in southwest Bangladesh, which concludes that as long as the underlying causes of poverty remain, adaptations will be limited, stopgap efforts. 
Therefore, the case-study evidence highlights that reciprocation - non-monetized and monetized trading - leads to an emphasis on economic capital albeit in localized ways. Social capital is important, but less potent unless it is linked to other forms of capital. It is important to highlight that it is a necessary precondition of sustainable modes of economic development. Placing economic solutions into/onto such communities will not gain the traction necessary, traction without some form of social organization, trust and reciprocation and exchange that will allow an (exchange based) economy to grow. In other words, it deals with a particular aspect of market failure; it is restorative by allowing the community to build the necessary infrastructures (and enabling technologies) to engage in social exchange and local circuits of capital.

\section{Conclusion}

This paper has highlighted a complex causality implicit in social capital-resilience relations; however, it also indicates their mutually reinforcing quality. While the case study emphasizes the importance of maintaining a diversity of types of social capital-based support (with monetary support as a subset) for building proactive resilience, the poor's strongest networks are commonly with their family or kin. The potential of these networks to enhance resilience to uncertain future climate change must not be overemphasized. While they can provide important sources of coping (albeit limited to reactive resilience), the evidence suggests that there appears to be limited opportunity for such networks to allow people to adapt to stresses, as the level of support these networks can provide is constrained given the socioeconomic and cultural fabric.

Furthermore, this paper highlights the dangers of uncritically importing social capital and the ineffective use of the term resilience (i.e. as something that can be achieved through maintaining the status quo) in research and policy discourses on climate adaptation. Clearly, this case study establishes that despite the conceptual advances in resilience and social capital theory, its utility and practical application are hampered by a lack of attention to social relations and power inequalities, which risks reinforcing vulnerability rather than addressing the underlying factors that determine vulnerability. The evidence underlines exclusionary forms of social capital at the household and community level, in particular how circuits of control and ownership of assets simply reproduce exclusion and injustice and make notions of social capital risible. Furthermore, while sudden devastating events can be reframed as opportunities for progress and positive change, this paper emphasizes that periods of crisis can create opportunities for negative forms of human agency. In particular, some local leaders after Cyclone Sidr reinforced their resilience, through practices of bribery in the 
allocation and distribution of relief. In other words, social ties that are used by elite groups to reproduce the status quo (i.e. reactive resilience) can perpetuate oppression and poverty.

Therefore, the case study emphasizes the importance of reformulating the concept of resilience with a vulnerability focus. Specifically, it underlines the importance of developing a deeper understanding of the contours of petty power (including the role of informal and formal leaders), and how they interact with more structured inequities, including gender and access to resources. Thus this study emphasizes the need for the more radical, proactive version of resilience, as a basis for socially inclusive and more sustainable responses to crises in the context of future climate change.

\section{Acknowledgements}

The Institute of Spatial and Environmental Planning, Queen's University Belfast financially supported this research. This research also benefitted from the institutional support of Bangladesh Centre of Advanced Studies, and Rupantar in Khulna and Mongla. The author thanks Nibras Sakafi, Mohsina Mahin and Ataul Karim for their translation during fieldwork. In particular, I thank the village inhabitants of Kolatola and South Kainmari for their generous participation in this study. The author thanks Brendan Murtagh, Geraint Ellis, Dan Brockington and the anonymous reviewers whose comments helped clarify the arguments of the paper. The author bears full responsibility for the text in the paper.

\section{References}

Adger, W.N. (2003). Social capital, collective action, and adaptation to climate change. Economic Geography, 79(4), 387-404.

Adger, W.N., Agrawala, S., Mirza, M.M.Q., Conde, C., O’Brien, K., Pulhin, J.,...Takahashi, K. (2007). Assessment of adaptation practices, options, constraints and capacity. In M.L. Parry, O.F. Canziani, J.P. Palutikof, P.J. van der Linden, \& C.E. Hanson (Eds.), Climate Change 2007: Impacts, adaptation and vulnerability. Contribution of Working Group II to the Fourth Assessment Report of the Intergovernmental Panel on Climate Change (pp. 717-743). Cambridge: Cambridge University Press.

Adger, W.N., Arnell, N.W., \& Tompkins, E.L. (2005). Successful adaptation to climate change across scales. Global Environmental Change, 15, 77-86.

Adger, W.N., Huq, S., Brown, K., Conway, D., \& Hulme, M. (2003). Adaptation to climate change in the developing world. Progress in Development Studies, 3(3), 179-195. 
Agrawala, S., Ota, T., Ahmed, A.U., Smith, J., \& van Aalst, M. (2003). Development and climate change in Bangladesh: Focus on coastal flooding and the Sundarbans. Paris: OECD (Organisation for Economic Co-operation and Development).

Alam, K.,Hussain, F., Hossain,K.,\& Saadi, S. (2009). Comparative risk profile in climate change of the selected agro-ecological zones in Bangladesh: An assessment and outline of disaster risk reduction strategy for Oxfam GB Bangladesh (first draft report). Ilford: ThinkAhead Consulting.

Asiatic Society of Bangladesh. (2008). National encyclopedia of Bangladesh [CD]. Dhaka: Author.

Boyd, E., Osbahr, H., Ericksen, P., Tompkins, E.L., Lemos, M.C., \& Miller, F. (2008). Resilience and 'climatizing' development: Examples and policy implications. Development, 51 (3), 390-396.

Brand, F.S., \& Jax, K. (2007). Focusing the meaning(s) of resilience: Resilience as a descriptive concept and a boundary object. Ecology and Society, 12(1), 23. Retrieved November 29, 2012, from http://www.ecologyandsociety.org/vol12/iss1/art23/

Cabinet Office. (2011). Strategic national framework on community resilience. Whitehall: Author.

DFID. (2009). Eliminating world poverty: Building our common future. Norwich: TSO (The Stationery Office).

Dovers, S.R., \& Handmer, J.W. (1992). Uncertainty, sustainability and change. Global Environmental Change, 2(4), 262-276.

Duvendack, M., Palmer-Jones, R., Copestake, J.G., Hooper, L., Loke, Y., \& Rao, N. (2011). What is the evidence of the impact of microfinance on the well-being of poor people? London: EPPI-Centre, Social Science Research Unit, Institute of Education, University of London.

Featherstone, D., Ince, A., Mackinnon, D., Strauss, K., \& Cumbers, A. (2012). Progressive localism and the construction of political alternatives. Transactions of the Institute of British Geographers, 37(2), 177-182.

Fine, B. (2010). Theories of social capital: Researchers behaving badly. London: Pluto Press.

Folke, C. (2006). Resilience: The emergence of a perspective for social-ecological systems analyses. Global Environmental Change, 16, 253-267.

Gallopín, G.C. (2006). Linkages between vulnerability, resilience, and adaptive capacity. Global Environmental Change, 16(3), 293-303.

Government of Bangladesh. (2008). Cyclone Sidr in Bangladesh: Damage, loss, and needs assessment for disaster recovery and reconstruction. Dhaka: Author. Retrieved May 
19 ,

http://gfdrr.org/docs/AssessmentReport Cyclone\%20Sidr Bangladesh 2008.pdf

Granovetter, M. (1973). The strength of weak ties. The American Journal of Sociology, 78(6), 1360-1380.

Grootaert, C. (1997). Social capital: The missing link? (Social Capital Initiative Working Paper No. 3). Washington, DC: The World Bank.

Gupta, J., Termeer, C., Klostermann, J., Meijerink, S., van den Brink, M., Jong, P.,... Bergsma, E. (2010). The adaptive capacity wheel: A method to assess the inherent characteristics of institutions to enable the adaptive capacity of society. Environmental Science and Policy, 13(6), 459-471.

Harriss, J. (2002). Depoliticizing development: The World Bank and social capital. London: Anthem Press.

Harriss-White, B. (2002). A note on destitution (QEH Working Paper 86). Oxford: Queen Elizabeth House, University of Oxford.

Huq, S., \& Ayers, J. (2008). Climate change impacts and responses in Bangladesh. Brussels: Policy Department Economy and Science, European Parliament.

IPCC. (2007). Summary for policymakers. In M.L. Parry, O.F. Canziani, J.P. Palutikof, P.J. van der Linden, \& C.E. Hanson (Eds.), Climate Change 2007: Impacts, adaptation and vulnerability. Contribution of Working Group II to the Fourth Assessment Report of the Intergovernmental Panel on Climate Change (pp. 7-22). Cambridge: Cambridge University Press.

Khan, A., Mojumder, S.K., Kovats, S., \& Vineis, P. (2008). Saline contamination of drinking water in Bangladesh. The Lancet, 371(9610), 385.

Klein, R., Nicholls, R., \& Thomalla, F. (2003). Resilience to natural hazards: How useful is this concept? Environmental Hazards, 5(1-2), 35-45.

Law, A., \& Mooney, G. (2006). The maladies of social capital II: Resisting neo-liberal conformism. Critique, 34 (3), 253-268.

Levitas, R. (2000). Community, utopia and new labour. Local Economy, 15(3), 188-197.

Mahmed, T., \& Prowse, M. (2012). Corruption in cyclone preparedness and relief efforts in coastal Bangladesh: Lessons for climate adaptation? Global Environmental Change, 22, 933-943.

Mallick, D.L., \& Alauddin, S.M. (2010). Baseline survey report (draft): Local capacity building and advancing adaptation to climate change in the Central, South Central and South Western coastal Bangladesh. Dhaka: BCAS.

Mertz, O., Mbow, C., Reenberg, A., Genesio, L., Lambin, E.F, D'haen, S.,... Sandholt, I. (2011). Adaptation strategies and climate vulnerability in the Sudano-Sahelian region of West Africa. Atmospheric Science Letters, 12(1), 104-108. 
Moser, C. (1998). The asset vulnerability framework: Reassessing urban poverty reduction strategies. World Development, 26 (1), 1-19.

Newman, L.L., \& Dale, A. (2005). Network structure, diversity, and proactive resilience building: A response to Tompkins and Adger. Ecology and Society, 10(1), 2. Retrieved January 11, 2010, from http://www.ecologyandsociety.org/vol10/iss1/resp2/

O'Brien, K. (2011). Responding to environmental change: A new age for human geography? Progress in Human Geography, 35(4), 542-549.

Osbahr, H., Twyman, C., Adger,W.N., \& Thomas, D.S.G. (2010). Evaluating successful livelihood adaptation to climate variability and change in southern Africa. Ecology and $\begin{array}{lllll}\text { Society. } & \text { Retrieved } & \text { September } & \text { 2010, from }\end{array}$ http://www.ecologyandsociety.org/volXX/issYY/artZZ/

Park, S.E., Marshall, N.A., Jakku, E., Dowd, A.M., Howden, S.M., Mendham, E., \& Fleming, A. (2012). Informing adaptation responses to climate change through theories of transformation. Global Environmental Change, 22(1), 115-126.

Paton, D., Millar, M., \& Johnston, D. (2001). Community resilience to volcanic hazard consequences. Natural Hazards, 24 (2), 157-169.

Pelling, M. (2003). The vulnerability of cities: Natural disaster and social resilience. London: Earthscan.

Pelling, M., \& High, C. (2005). Understanding adaptation: What can social capital offer assessments of adaptive capacity? Global Environmental Change, 15(4), 308-319.

Portes, A. (1998). Social capital: Its origins and applications in modern sociology. Annual Review of Sociology, 24, 1-24.

Pouliotte, J., Smit, B., \& Westerhoff, L. (2009). Adaptation and development: Livelihoods and climate change in Subarnabad, Bangladesh. Climate and Development, 1, 31-46.

Putnam, R. (1995). Turning in, turning out: The strange disappearance of social capital in America. Political Science and Politics, 28, 664-683.

Roodman, D., \& Morduch, J. (2009). The impact of microcredit on the poor in Bangladesh: Revisiting the evidence (CGD (Center for Global Development) Working Paper 174). Washington, DC: Author. Retrieved June 3, 2011, from http://www.cgdev.org/content/publications/detail/1422302

Rotberg, F.J.Y. (2013). Social networks, brokers, and climate change adaptation: A Bangladeshi case. Journal of International Development, 25, 599-608.

Sen, A. (1990). Gender and cooperative conflicts. In I. Tinker (Ed.), Persistent inequalities: Women and world development (pp. 123-149). New York, NY: Oxford University Press.

Smit, B., \& Pilifosova, O. (2001). Adaptation to climate change in the context of sustainable development and equity. In J.J. McCarthy, O.F. Canziani, N.A. Leary, D.J. Dokken, \& 
K.S. White (Eds.), Climate Change 2001: Impacts, adaptation, and vulnerability. Contribution of Working Group II to the Third Assessment Report of the Intergovernmental Panel on Climate Change (pp. 877-912). Cambridge: Cambridge University Press.

Sutherland, K., Smit, B., Wulf, V., \& Nakalevu, T. (2005). Vulnerability to climate change and adaptive capacity in Samoa: The case of Saoluafata village. Tiempo, 54, 1-15.

Swain, R.B., Van Sanh, N., \& Van Tuan, V. (2008). Microfinance and poverty reduction in the Mekong Delta in Vietnam. African and Asian Studies, 7(2-3), 191-215.

Tompkins, E.L., \& Adger, W.N. (2004). Does adaptive management of natural resources enhance resilience to climate change? Ecology and Society, 9(2), 1-14. Retrieved September 2, 2007, from http://www.ecologyandsociety.org/vol9/iss2/art10

Traerup, S.L.M. (2012). Informal networks and resilience to climate change impacts: A collective approach to index insurance. Global Environmental Change, 22, 255-267.

United Nations Development Programme. (2007). Human development report 2007/2008. Fighting climate change: Human solidarity in a divided world. New York, NY: Palgrave Macmillan.

United Nations Environment Programme. (2008). UNEP climate change strategy. Nairobi: Author.

Walker, B., Carpenter, S., Anderies, J., Abel, N., Cumming, G., Janssen, M.,...Pritchard, R. (2002). Resilience management in social-ecological systems: A working hypothesis for a participatory approach. Conservation Ecology, 6(1), 14. Retrieved October 15, 2007, from http://www.consecol.org/vol6/iss1/art14

Wolf, J., Adger,W.N., Loronzoni, I., Abrahamson, V., \& Raine, R. (2010). Social capital, individual responses to heat waves and climate change adaptation: An empirical study of two UK cities. Global Environmental Change, 20(1), 44-52.

Woolcock, M. (2001). The place of social capital in understanding social and economic outcomes. Canadian Journal of Policy Research, 2(1), 11-17.

World Bank. (2009). Making development climate resilient: A World Bank strategy for subSaharan Africa (Report No. 46947-AFR). Washington, DC: Author. Retrieved November 9, 2010, from http://siteresources.worldbank.org/INTAFRICA/Resources/ClimateChangeStrategyReport2010-Full vNolmages.pdf

Yunus, M. (1999). Banker to the poor. New York, NY: Public Affairs. 


\footnotetext{
i The local and regional partners for this project and other local NGOs working in the area indicated that the case-study villages have a high proportion of poor village inhabitants. However, there is no detailed poverty data available at the village level.

ii At the time of this study, the exchange rate was approximately $£ 1.00=100 \mathrm{tk}$.

iii Follow-up questions were used only when responses were not fully understood, vague or ambiguous, or when more in-depth information was required.

iv While there was no explicit indication of the focus on climate-related stresses to interviewees at the outset (i.e. introductions and category 1 questions), it was introduced at later stages of the interviews.

${ }^{v}$ While this paper is based on empirical findings from two different case-study locations, the evidence has highlighted common patterns, challenges and solutions between the two (i.e. their similarities). Therefore, this paper will only refer specifically to case-study village 1 or 2 when the evidence is specific to that particular location (i.e. their differences), otherwise the evidence presented refers to the finding of both case-study villages 1 and 2, highlighting that this research is not dealing with unique effects.

vi This paper adopts Harriss-White's (2002) definition of destitution, which combines the notion of economic destitution ('having almost nothing') with the notion of social and political destitution ('being almost nothing'). 'It involves the absence of any control over assets and the loss of access to income from one's own labour [...] It is also the loss of enfranchisement or entitlements which are not pricemediated, the collapse of moral units above the level of the individual, the draining away of social support, loss of access to "common" property and public goods and services, the disappearance of political legitimacy and citizenship' (pp. 1-4).

vii While there is empirical evidence that microcredit alleviates poverty (see Mertz et al., 2011; Swain, Van Sanh, \& Van Tuan, 2008), the UK government-funded systematic review of the impact of microfinance concluded that robust data on its nature, magnitude and effects are both limited and inconclusive over the last 30 years (Duvendack et al., 2011).

viii The Chairperson plays a central role in all activities of the union parishad. He/she is the administrative head; therefore, the chairperson's approval is required for all activities in the union parishad. They have a broad range of responsibilities, for example duties that focus on revenue collection and budgetary issues.
} 